\title{
EDMUND HUSSERL ON LEIB AND TRANSCENDENTAL IDEALISM: SKETCHING A COUNTER-APPROACH BASED ON HUSSERLIANA XXXVI ${ }^{1}$
}

\author{
DANIELE DE SANTIS
}

\begin{abstract}
Contrary to a certain way of understanding Husserl's philosophy, according to which the Husserlian phenomenology of Leib, or "lived-body", would stand in a straightforward opposition to the thesis of "transcendental idealism", the present paper will advance the claim that, for Husserl, the idea of an actual and embodied subjectivity is not only compatible with the claims of idealism, but is the very concept on which Husserl's arguments to justify transcendental idealism build. The text is divided into two main parts: while part one will provide a quick, but systematic, presentation of what Husserl himself means by "transcendental idealism", the second section will discuss Husserl's understanding of the concept of Leib, of what Husserl refers to as "aesthetic synthesis", and of the role that such notions play in his line of thought.
\end{abstract}

\section{0.}

According to a quite accepted line of interpretation that dates back at least to Merleau-Ponty's breakthrough reading of Husserl, notably of Ideen II (Le philosophe et son ombre ${ }^{2}$ ), the "discovery" of the Leib on the part of the father of

1 The present text is a re-elaboration of a paper originally presented at a workshop on Lived Body and Affectivity, (Charles University, Prague, October 2, 2017). I am very grateful to the organizer of the workshop, K. Novotný, and to those who attended and presented at the workshop: I. Quepons, J. Čapek and J. Mensch.

2 Merleau-Ponty Maurice, Signes, Paris, Gallimard, 1960, pp. 259-295: for example p. 290. See the detailed account by Molteni Gioacchino, Introduzione a Michel Henry. La svolta della fenomenologia, Milan, Mimesis, 2005, notably pp. 19-52. Creative Commons Attribution License (http://creativecommons.org/licenses/by/4.0). 
phenomenology would introduce an unsolvable tension - in the thought itself of Husserl - between the fact of the body (which suddenly would claim the right to be "constitutive" and not simply "constituted") and the very idea of intentional constitution, hence Husserl's ultimate aspiration to ground "transcendental idealism" (construed as a mere relic from his early "intellectualism"). Now, without directly discussing such a view (for it would take us in a completely different direction), we will strive to show that there is a great deal of truth to it: Husserl comes to acknowledge, in fact, the "constitutive" role of the body. ${ }^{3}$ Nevertheless - this being where Merleau-Ponty and those who follow him go astray - , rather than presenting itself as a "theme" somehow irreconcilable with the claims of "transcendental idealism" (whatever these might amount to), the Leib is, for Husserl, the very key to transcendental idealism. The point is not just to contend - contra Merleau-Ponty for example - that "transcendental idealism" and the "body" can be finally reconciled: Husserl's aim is to prove (he speaks of Beweis) transcendental idealism not in spite of, but based on, the phenomenology of the Leib.

Let us start by explaining what this paper will not deal with. First of all, this paper does not want to be an "evaluation" of Husserl's transcendental idealism; for, it seems to us that the discussion of the Husserlian idealism and the question as to whether it is a self-consistent and coherent doctrine should always be based upon a clear understanding of what the "thesis" of transcendental idealism actually consists in, as well as of the actual problem, for whose solution such a thesis is appealed to by Husserl. Second, this paper is not going to raise the quite "thorny" question as to whether Husserl is right in claiming that his originally descriptive phenomenology must necessarily turn into, or entail, transcendental idealism. ${ }^{4}$

In the present paper, we will first strive to clarify the "problems" Husserl is dealing with when he introduces the doctrine of transcendental idealism; we will then elaborate on what Husserl means by "transcendental idealism" (for many different claims seem to fall under this general "label") to shed some light on the role played by the Leib. Now, whether Husserl's Beweise are successful is a question that this paper cannot and does not intend to tackle, nor will it try to address the problem of the constitution or self-constitution of the Leib: its main interest is to

3 Even though Husserl does not seem to have explicitly employed such an "expression," what we mean to emphasize by speaking of the "constitutive" role of the body is the central function played by Leib in the constitution of the different layers of the material world at both its solipsistic and inter-subjective levels. I am grateful to Ignacio Quepons for his objection.

4 For a more extensive introduction to the problem, see Loidolt Sophie, "Transzendentalphilosophie und Idealismus in der Phänomenologie", in Metodo. International Studies in Phenomenology and Philosophy, 2015, pp. 103-135, who also presents a useful description of the most recent positions on the topic. 
contribute to clearing up what transcendental idealism actually stands for (in its relation to the notion of Leib).

As the reader will realize, the counter-approach hinted at by the title is nothing else but Husserl's own approach!

\section{1.}

Before we embark on our analysis, three remarks are necessary. First, whatever the turn of phrase transcendental idealism will end up meaning, it is crucial to keep in mind that, depending on the context of its introduction, it can have either a positive or a negative sense. In other words: the talk itself of transcendental idealism can either boil down to positively stating and supporting a specific thesis and claim or to negatively excluding a specific thesis and claim. Second, the way in which Husserl outlines his Beweise is based upon what could be called (in a positive sense) the most positivistic aspect of his thought - consisting in the demand for "justified" and "legitimized" claims (statements). Accordingly, he speaks of Ausweis, and of a series of variations thereupon, such as ausweisen or ausweisende Erfahrung ${ }^{5}$, his main concern being to see in what sense, and to what extent, certain statements and claims (e.g., "there exists a world behind this world") can or cannot be justified, can or cannot be the object of an ausweisende Erfahrung. ${ }^{6}$ Finally, Husserl's talk of transcendental idealism refers to a very specific understanding of the term "world," namely, the "material world," which is what he also calls Natur, nature as "the first form of objectivity" (to use the language of the Cartesian Meditations). ${ }^{7}$

\section{2.}

For the sake of brevity, and to avoid any preliminary assumption about what Husserl specifically means by "transcendental idealism," the following series of distinctions bearing on the relation between "consciousness" and "objectuality" can be proposed.

On the most general level, Husserl explores the connection between "consciousness" - as a "pure region," namely, as a mere series of Bewusstseins-Zusam-

5 Hua III/1, \$47.

6 '"Logisch' möglich ist freilich die hypothetische Annahme eines Realen außerhalb dieser Welt, ein analytisch-formaler Widerspruch liegt darin offenbar nicht. Fragen wir aber nach den Wesensbedingungen ihrer Geltung, nach der durch ihren Sinn geforderten Art ihrer Ausweisung, fragen wir nach der Art der Ausweisung überhaupt, die prinzipiell durch die Thesis eines Transzendenten [...] bestimmt ist" (Hua III/1, p. 113).

7 Hua I, pp. 149-164. 
menhänge - and its "objects" as "correlates" of such and such a Zusammenhang (I). This extremely general co-respondence is to be immediately considered according to the divide between "possible consciousness" (whose correlate is a "possible ideal" or eidos) and "actual consciousness" (whose correlate is an "individual objectuality") $^{8}$ (II). Now, consciousness being "actual," its relevant "objectuality" is the correlate, not just of a Bewusstseinszusammenhang, but of a specific Erfahrungs-Zusammenhang. As Ideen... I (\$47) phrases it: "the correlate of our factual experience, called 'actual world' (is) just one special case among a manifold of possible worlds and non-worlds which, for their part, are nothing else but the correlates of essentially possible modifications of the idea 'experiencing consciousness', with more or less orderly connections of experience" 9 . What Ideen... I (\$\$47-49) is really interested in bringing to the fore is not the world's dependence on consciousness, but the idea that what we call the "correlate" of an erfahrendes Bewusstsein covers a wide range of different cases: It can be "this" world, a more or less "deviating" or "diverging" Abwandlung thereof, or even that sort of radical "modification" that Husserl refers to as Unwelt (III). If this is the case, then the notion of a wirkliches or erfahrendes Bewusstsein (which, as Husserl points out, has no Seele or Leib ${ }^{10}$ ) does not suffice to discriminate between Welten and Un-Welten - for they all can count as an actual correlate: Even a non-world, in fact, corresponds to a certain connection of experience, though a very unstable or chaotic one. ${ }^{11}$ Hence, what is required is an "existent" subjectivity whose correlate is an "existent" world, namely, a leibliche Subjektivität: "The possibility of the experience of a thing-world (Dingwelt) [...] presupposes that the experiencing subject itself (das Erfahrende) belongs to the experienced world (der erfahrenen Welt angehört) inasmuch as it has a body in this world (er einen Leib in dieser Welt hat)"12 (IV). In other words: The possibility of experience of a thing-world (which corresponds to what in Ideen... I Husserl simply calls "world") presupposes a subjectivity that belongs to the world and - by means of its having a body and, hence, being a leibliche Subjektivität - is "part" of it. Now, as we shall soon see, even IV is not enough for Husserl. Indeed, one could immediately raise the questions as to whether what Husserl calls "the possibility of the experience of a thing-world" will simply and exclusively hinge

\footnotetext{
Hua XXXVI, pp. 73-74.

Hua III/1, p. 100.

Hua III/1, p. 119.

11 "in that case it could be that, to some extent, raw unity-formations become constituted, transient bearers for intuition, which were mere analogues of intuitions of physical things because quite incapable of constituting conservable 'realities', enduring unities 'that exist in themselves, whether or not they are perceived"' (Hua III/1, pp. 103-104).

12 Hua XXXVI, p. 133.
} 
upon a leibliche Subjektivität construed only as an "animal" one (ein erfahrendes Animal) (IV')13, or if it must be a "spiritual" leibliche Subjektivität (V); and, in this case, whether such a geistige Subjektivität must be - ultimately and necessarily a "human subjectivity" (menschliche Subjektivität) (VI).

All these different specifications can be represented as follows:

(I) Bewusstseins-Zusammenhänge «—» Object as the Correlate of such and such a
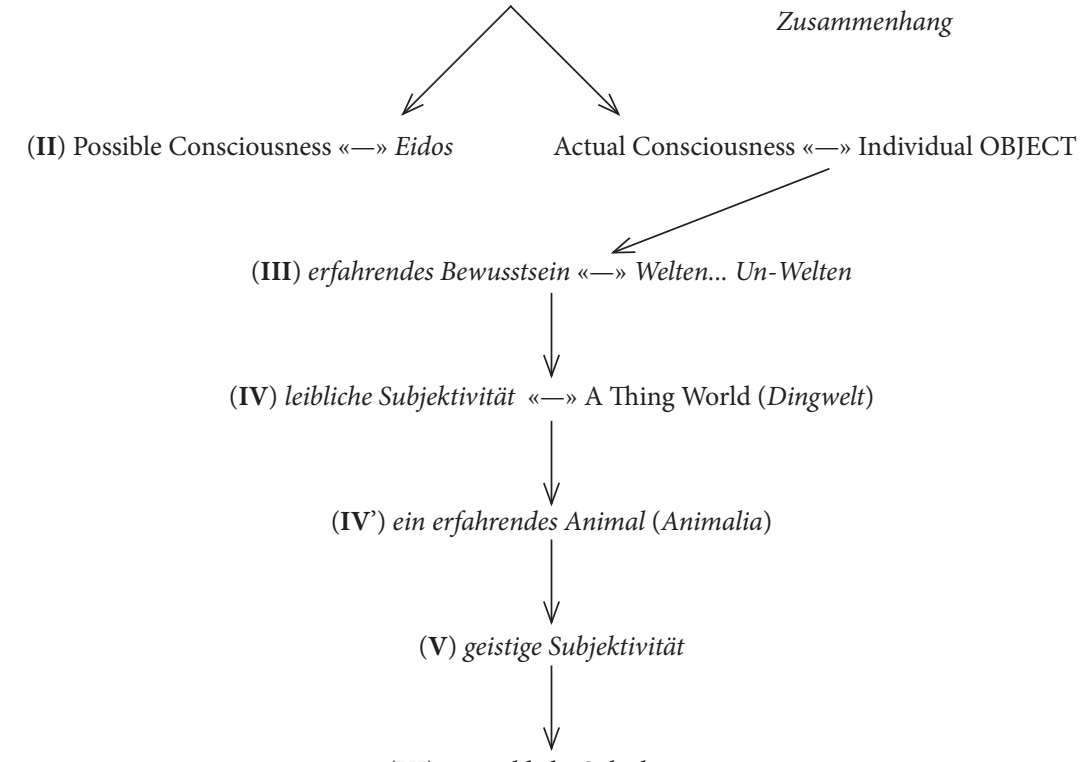

(VI) menschliche Subjektivität

Let us immediately point out that, for the sake of our problems here (a better understanding of the relations between transcendental idealism and the notion of Leib), our analysis will not step beyond IV and IV' - which means that we will not even attempt to address the question as to VI (for it would take us far beyond the limited scope of this investigation).

13 As is evident from reading Ideen... I ( $\$ 53$ : Die Animalien und das psychologische Bewusstsein), the term Animalien does not mean the same as Tier, for it express a "genus," i.e., what Menschen and Tieren have in common: their being two different types of leibliche Subjektivität. 
In light of this diagram, a second series of remarks imposes itself. Regardless of Husserl's own way of framing it, if "idealism" is, as in the words of Edith Stein, one of the possible solutions to the question of whether the objects of our experience have an existence independent of consciousness ("ob die Gegenstände unserer Erfahrung eine von allem Bewusstsein unabhängige Existenz haben") ${ }^{14}$, then the issue can be addressed, and the question eventually answered, only if we place ourselves at the level of IV (leibliche Subjektivität + "existent" world). Now, if this is the case, then it is a mistake to conflate this problem with the question of whether consciousness is in general "possible" without "nature" and vice versa (= "1. ist ein Bewusstsein denkbar, dem keine Natur entspricht? 2. ist eine Natur denkbar, wenn ihr kein Bewusstsein entspricht?") ${ }^{15}$. This problem would in fact correspond to III, and its solution would have no bearing upon the above Existenz-question. If we are on the right track, then it is clear why in Ideen I - where his sole interest is to establish the possibility of a new science ("phenomenology") by bringing to light a brand new field of investigation ("pure consciousness" as an Ur-Region) - Husserl never characterizes his position as "transcendental idealism": the latter is not and should not be understood based upon the relation between two Ur-Regionen, like the Ur-Region "pure consciousness" and the Ur-Region "world."

This being said, let us see how Husserl himself presents the very idea of transcendental idealism. To put it as bluntly as possible, we should ask ourselves:

(i) What do the claims of transcendental idealism really consist in?

(ii) What are the problems for which transcendental idealism seems to represent the solution?

Let us first consider ii, the problems.

\section{1.}

On a general level (A), the issue Husserl is tackling is that of die Annahme einer existierenden Welt; in other words, and given all the possible translations of the German Annahme, what does it mean for a world to be "assumed," "presupposed," or "accepted" as "existent" (in Husserl's words: was liegt in der Annahme einer exist-

14 Stein Edith, Einführung in die Philosophie, Freiburg, Herder, 2010, p. 69.

15 Ibid., p. 72. 
ierenden Welt ${ }^{16}$ ? It can be easily urged that what Husserl is really trying to clarify is the sense of the term "existence" or, better, what is involved in "the idea of something existent" (die Idee eines Existierenden überhaupt). On a more specific level (B), the problem turns out to be that of possible or other worlds (die Möglichkeit anderer Welten) - the question amounting not simply to explaining what it would mean for a world to be assumed as existent given a set of possible alternatives, but first and foremost to ruling out the real possibility of other worlds. Historically speaking, one could maintain that while the first alternative (B') corresponds to Leibniz (one real world against the backdrop of an infinite number of "possibles" in God's mind) ${ }^{17}$, the second one (B") is represented (just to recall a contemporary example) by David Lewis' modal realism (i.e., there exists an infinite number of actual or real worlds, even in complete isolation from one another) ${ }^{18}$. On an even more specific level $(\mathbf{C})$, the issue is that of the possibility of establishing the identity of the material world (read: the one Natur) ${ }^{19}$, which can be construed either $\left(\mathbf{C}^{\prime}\right)$ as a variation on B" (i.e., the many real worlds simply turning out to be the one and the same real world) or (C") as the problem of the constitution of the one world over and above the many (cultural and social) Um-Welten.

To present this series of problems in a clear way, one could propose the following diagram:

(A) Die Idee eines Existierenden überhaupt

(B) Die Möglichkeit anderer Welten

(B') One Existent World vs. Many Possible Worlds (e.g., Leibniz)

(B") “There are countless other worlds" (e.g., D. Lewis)

(C) Identity of the Material World

16 Hua XXXVI, p. 117.

17 As Husserl points out in the Cartesian Meditations: "Naturally Leibniz is right when he claims that infinitely many monads and groups of monads are conceivable, but it does not follow that all these possibilities are compossible; and again when he says that infinitely many worlds could have been created, but no more than one at the same time (nicht mehrere zugleich), since they are incompossible" (Hua I, p. 167). On this specific topic and text, see our "'Metaphysische Ergebnisse': Phenomenology and Metaphysics in Edmund Husserl's Cartesianische Meditationen (\$60): An Attempt at Commentary," in: Husserl Studies, 2018.

18 "I advocate a thesis of plurality of worlds, or modal realism, which holds that our world is but one world among many. There are countless other worlds. [...] They are isolated: there are no spatiotemporal relations at all between things that belong to different worlds. Nor does anything that happens at one world cause anything to happen at another," (Lewis David K., On the Plurality of Worlds, Oxford, Blackwell, 1986, pp. 1-5).

Hua XXXVI, p. 136. 

(C') Variation upon B"20
(C") The one World vs. The Many Um-Welten

Before we move on, three observations are necessary. First, as should already be evident, the way Husserl himself frames his battery of problems has prima facie nothing to do with the question as to whether the existence of the world depends on consciousness; second, by including "the idea of something existent," none of these questions can be successfully raised at III, for they all need at least IV, namely, the "existence" of a leibliche Subjektivität as a correlate. In other words: none of these questions can be tackled, nor can transcendental idealism be eventually proposed as a means to address them, by sticking to III and without bringing in the notion of Leib, which, accordingly, does not stand in opposition to it. Finally, and as announced at the outset (0), to address the above issues $(\mathbf{A}, \mathbf{B}, \mathbf{C})$ means to either prove something (what it is like for something to be assumed as existent) or to dismiss it (the existence of multiple real worlds à la Lewis).

\section{2.}

Let us now move on to the question regarding the "claims" of transcendental idealism (i). In light of the above distinctions ( A, B, C), these claims, too, can be divided in different groups, each of them corresponding to one of those "problems."

As Husserl points out, (A) the assumption of something existent in general necessarily goes hand in hand with the idea of an Ausweisung of such an existence, namely, with the assumption of a real and actual ego "with a specific and determined stream of experience" (ein bestimmtes Ich mit einem bestimmten Erfahrungsstrom) ${ }^{21}$, and of "actual experience-things" (die aktuellen Erfahrungsdinge) as Träger of "experience-motivations" (Erfahrungsmotivationen). What Husserl is elaborating on here is not simply the "co-relation" between an actual subjectivity and something existent: the point is not to say that the assumption of something existent corresponds to a possibly actual subject able to experience it; the point is that, unless we assume these "things" as Träger of Motivationen of a determined stream of experience, we cannot rule out the hypothesis that what we call the existent world is just $a$ possible world among others (B'), or just an actual world among many infinite actual ones (B"). A leads immediately to $\mathbf{B}$ : "To the assumption of

20 For example, Hua XXXIX, pp. 215-218, Beilage XVII: Zwei Welten für ein Ich.

21 Hua XXXVI, p. 119. 
a determined and existent world there belongs a determined ego with a determined stream of experience: thereby the possibility of other worlds is excluded, not included (dieser schließt die Möglichkeit anderer Welten nicht ein, sondern aus)"22. As should be evident (this being nevertheless the point we will have to elaborate on), the talk of Dinge as Träger of Motivationen refers back to the idea of a leibliche Subjektivität: for only if there exists a Leib can there also be "motivations." Were any of these components to be taken out, one would immediately fall back into III, and it would be impossible to speak of a determined and "existent" world: "To an ideally possible ego there belongs an ideally possible experience: an ideally possible experience, namely, a set of empty possibilities that include equally all possible worlds, therefore no determined world stands out"23). ${ }^{24}$

Husserl himself speaks of animalische Realitäten ${ }^{25}$, of Leib, as well as of erscheinender Leib ${ }^{26}$, of Leiblichkeit ${ }^{27}$, and of animalische Existenz ${ }^{28}$; in Ideen... II (\$14) Husserl clearly asserts that the so-called "animal realities" (animalische Realitäten) are to be characterized as beeselte Leiber ${ }^{29}$. Accordingly, and even if only in a preliminary way (preliminary in a very specific sense, as we will see later on), one can present Husserl's "transcendental idealism" as the thesis that

(TI.1) Die Annahme einer existierenden Welt requires (fordert) "at least" an animalische, or leibliche Existenz with a relevant system of Motivationen.

The same claim is made with respect to $\mathbf{C}\left(\mathbf{C}^{\prime}\right.$ and $\left.\mathbf{C}^{\prime}\right)$. Text No. 7 from Husserliana XXXVI is dedicated to expanding on the idea that an animalische Existenz

22 Hua XXXVI, p. 119.

23 Hua XXXVI, p. 120.

24 It would be very interesting to compare Husserl's position with Giovanni Gentile's idealismo attuale, notably with what he asserts in Ch. VII (Il positivo come autoctisi), $\$ 12$ (L'individuo come positione di sé o spirito), where a very similar claim is advanced, i.e., the one according to which the determination of an "actual reality" necessarily requires the self-position of an actual subjectivity: "E se si prescindesse da questo centro di riferimento di tutta l'esperienza, che è l'Io, intorno al quale essa si organizza e sistema, la realtà si giustaporrebbe alle cose vedute fantasticando e a tutta la vita nel sogno, senza possibilità di discriminazione e valutazione. Il che vuol dire, che il vero e univo positive à l'atto del soggetto che si pone come tale; e ponendo sé, pone in sé, come suo proprio elemento, ogni realtà che è positiva per questa suo rapporto di immanenza all'atto in cui l'Io si pone in modo sempre più ricco e più complesso. Di guisa che, sottraete la vostra soggettività del mondo che contemplate, e il mondo diventa un rêve, senza positività" (Gentile Giovanni, "Teoria generale dello spirito come atto puro", now in: Id., L’attualismo, Milano, Bompiani, 2014, p. 172).

Hua XXXVI, p. 125.

Hua XXXVI, p. 133, pp. 164-165.

7 Hua XXXVI, p. 134.

8 Hua XXXVI, p. 140.

9 Hua IV, p. 32. 
(a psychophysische one) is in fact required for the constitution of the one identical "world": "If it has already been demonstrated that the possibility of knowledge of a material world includes in itself the possibility of subjects, which belong to this world in an animal way - then what does this possibility mean? Can it merely be a logical possibility? (Wenn schon erwiesen ist, dass die Möglichkeit der Erkenntnis einer materiellen Welt in sich schließt die Möglichkeit von Subjekten, die animalisch dieser Welt angehören - was besagt diese Möglichkeit? Kann es eine bloß logische Möglichkeit sein?)"30. Husserl's answer is straightforward: Nein. What is required is a subjectivity endowed with specific Erfahrungsdispositionen, that is to say, with determined arrangements of what Husserl himself calls Empfindungs- und Wahrnehmungsmöglichkeiten.

\section{1.}

Now, after briefly presenting the problems $(\mathbf{A}, \mathbf{B}, \mathbf{C})$ Husserl is dealing with (2.1), and for which "transcendental idealism" represents the solution, and after providing a (2.2) preliminary characterization of what the thesis of transcendental idealism seems to mean (TI.1), it is now time to turn to the notion of Leib and leibliche Subjektivität.

\section{2.}

At the end of $\$ 33$ of Ideen... II Husserl is clear: what we have to oppose to "material nature" as a second kind of reality is not simply the soul, but a "concrete unity" of Leib und Seele, namely, an animalisches Subjekt ${ }^{31}$. When it comes to the notion of Leib, it is vital to keep in mind the distinction between: (a) der materielle Leib, the Leib as a Sache belonging to the material world; (b) the aesthesiologischer Leib, which builds upon (a) but is not to be reduced to it; finally, (c) der Willensleib, the body as an expression of the "freely acting spirit" (Geist) ${ }^{32}$.

The notion of Leib upon which Husserl builds his claims is (b): it is the aesthesiological body that includes (a) - it being "part" of the world (der erfahrenen Welt angehört; Subjekten, die animalisch dieser Welt angehören) - but not yet (c) - which leaves open the question of whether such a body is only the expression of a psychic

\footnotetext{
30 Hua XXXVI, p. 136.

31 Hua IV, p. 139.

32 Hua IV, p. 284.
} 


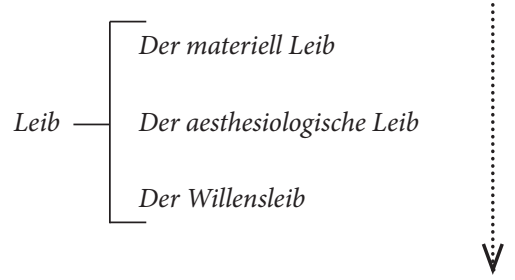

reality (psychophysische subjectivity) (IV') or of a "spiritual" (V), and eventually "human subjectivity" (VI). Now, the importance of our last remark is due to the fact that this distinction $(\mathrm{a}, \mathrm{b}, \mathrm{c})$ corresponds to the double distinction between real and intentional relations, and between aesthesiological and spiritual motivations.

Let us try to be clearer. When it comes to the material body, i.e., to the Leib just a "material" thing among other "material" things, what we have is a series of real relations holding between material things sic et simpliciter ${ }^{33}$. It is only with both (b) and (c) that "intentional" relations in general come in, and one can thereby speak of Motivation als Grundgesetzlichkeit ${ }^{34}$; hence, the distinction between (b) and (c) boils down to that between aesthesiological motivation and spiritual motivation. If we are to leave out (c), then the "system of motivations" we are looking for is one proper to (b), the aesthesiological one, which includes (a) and excludes (c).

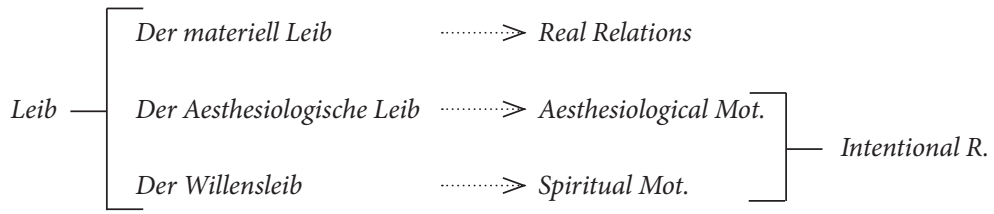

The transition from (a) to be (b) or, differently stated, the inclusion of (a) in (b) is made possible by what Husserl calls the "two totally different constituting functions" (konstituierende Funktionen) of the "data of sensations" (Empfindungen):

The first kind is the sensations that constitute, by means of the apprehensions allotted to them, corresponding features of the thing as such by way of adumbration. [...] The second kind is the "sensations", which do not undergo such apprehensions but which, on

33 Hua IV, p. 215.

34 Hua IV,p. 220. 
the other hand, are necessarily involved in all those apprehensions of the sensations of the first kind, to the extent that they, in a certain way, motivate those apprehensions ${ }^{35}$.

If this passage can misleadingly suggest the existence of "two" different species of sensations, in Ideen... III, Husserl clearly distinguishes the Empfindungen according to their "function," and thus speaks of data of sensations in der Funktion des Motivierenden (called "kinesthetic" sensations), and data of sensations in der Funktion des Motiviereten (also called "presenting" sensations) ${ }^{36}$. Unlike the account of Ideen... II, where only "one" of the two species of sensations seems to belong to the phenomenological domain of motivation, the "functional" description of Ideen... III holds both "types" as belonging to the domain of motivations (the two "types" being only two "functions"). More bluntly stated, the domain of aesthesiological motivation is a system including "motivating" and "motivated" data of sensations or, better, it includes both functions.

For the sake of our problems, we have reached an important stage. If, according to TI.1, what is required is a leibliche Subjektivität or animalische Existenz with a relevant "system of motivations," we now know what such a "system" is: it is a system of aesthesiological motivations, including data of sensations in both motivating and motivated functions. Were we to rephrase TI.1, we could write that Husserl's "transcendental idealism" consists in the thesis that

(TI.1') Die Annahme einer existierenden Welt requires (fordert) at least an animalische or leibliche Existenz, that is to say, a subject endowed with a system of aesthesiological motivations, including both "kinesthetic" and "presenting" sensations.

\section{3.}

If we ask in what this "system" results, or what it looks like, then Husserl will answer along the following lines:

Those sensations that undergo extensional apprehension (leading to the extended features of the thing) are motivated as regards the course they take either actually or possibly, and are apperceptively related to a motivating series, to a system of kinesthetic sensations, which freely unfold in an orderly connection in a such a way that if a free unfolding of one series of this system occurs (e.g., any movement of the eyes or fingers),

35 Hua IV, p. 57

36 Hua V, p. 14. 
then from the interwoven manifold as a motive, the corresponding series must unfold as motivated ${ }^{37}$.

Husserl speaks then of Motivationsbeziehungen, motivierte Ordnung and Ordnungszusammenhang, Reihe dieses Systems and motivierte Reihen, mögliche Wahrnehmungsreihen ${ }^{38}$. In short: such a system of motivations (as a conjunction of kinesthetic and presenting sensations) results in a "system" of perceptual "series" or even "lines" (as one could also translate Reihen) ${ }^{39}$ - some of them being mutually exclusive, as is the case, for example, with my Augen-Bewegungen (e.g., I can turn my eyes either to the right or to the left ${ }^{40}$ ); others, on the contrary, overlap - as is the case with different senses. Now, the crucial notion Husserl resorts to in order to characterize the intertwining of such perceptual series or lines is that of "aesthetic synthesis" (\$9): "Another function of the aesthetic synthesis is to unify with one another (miteinander $z u$ einen) the objectivities that are constituted in the various single spheres of the senses: e.g., the visual stratum of a thing with the tactile" 41 .

Were we again to rephrase TI.1, we could say Husserl's "transcendental idealism" consists in the thesis according to which:

(TI.1") Die Annahme einer existierenden Welt requires (fordert) at least an animalische or leibliche Existenz, namely, a subject endowed with a system of aesthetic syntheses.

\section{4.}

When we first introduced TI.1 (2.2), we said that it should be taken only as a preliminary definition. The time is now ripe to address such preliminary character.

As Ideen... II remarks at the end of $\$ 18(\mathrm{e})$, we have to "lift the abstraction we maintained up to now and take into consideration the conditions under which

\footnotetext{
Hua IV, pp. 57-58.

See also Hua XXXIX, p. 209: Strecke, and Linie des Systems der Kinästhesen.

9 "Ohne Beschauen kein optische Ausweisung, ohne Betasten keine haptische usf. Es müssen dabei kinästhetische Reihen in eigener phänomenologischer Charakterisierung ablaufen, verbunden mit zugehörigen Empfindungsreihen, die darstellende Funktion haben” (Hua XXXVI, p. 165).

"In this way, from the ordered system of sensations in eye movement, in head movement freely moved etc., there unfolds such and such a series in vision" (Hua IV, p. 58).

41 Hua IV, p. 20.
}

40 
the factual constitution occurs: i.e., that the experiencing subject is, in truth, not a solipsistic subject, but is one among many (under vielen)" 42 . Let us read Husserl:

As long as we take cases in which changes of the external world, feigned for us by an abnormal perceptual organ, are revealed as "semblances" by the testimony of the other organs, to that extent the distinction between "seeming" and what actually is is always given $[\ldots]$. But if we assume for once that a subject would always have only normal perceptions and would never undergo a modification of any of its organs, or on the other hand would undergo a modification, but one that allowed for no possibility of correction (loss of the entire field of touch, or mental diseases that alter the entire typical character of perception), then the motives for the distinction between "semblance" (Schein) and "actuality" (Wirklichkeit), assumed up to now, would be eliminated, and the level of "objective nature" could not be attained by such a subject.

Two remarks are necessary, one concerning the idea of an inter-subjective subjectivity, the other bearing on the distinction between Schein and Wirklichkeit:

- Husserl is clear: the distinction between Schein and Wirklichkeit cannot be assumed, nor can the level of "objective nature" ever be attained, unless a certain level of inter-subjectivity is brought in; here, inter-subjectivity means, first, infra-inter-subjectivity derived from the contrast (and eventual correction) between two or more of my own aesthetic syntheses, then actual inter-subjectivity due to the possible contrast (and eventual correction) between aesthetic syntheses belonging to "different" subjects. To give an example: "As I communicate to my companions my earlier lived experiences and they become aware of how much of these conflict (Widerstreit) with their world, constituted inter-subjectively and continuously exhibited by means of an harmonious exchange of experiences, then I become for them an interesting pathological object" 43 :

\section{Leibliche Subjektivität $\leftrightarrow$ Ding}

Infra-Subjective Alterity $\leftrightarrow$ Infra-Subjective Contrast and Correction (Solipsistic distinction between Schein and Wirklichkeit)

Inter-Subjective Alterity $\leftrightarrow$ Inter-Subjective Contrast and Correction (Inter-Subjective distinction between Schein and Wirklichkeit)

42 Hua IV, p. 78

43 Hua IV, p. 80. 
The relation to a manifold of leibliche Subjektivitäten enters into the apprehension of a thing as an objective and actual one (objektiv wirklich) and becomes constitutive.

- Let us now try to relate the distinction between Schein and Wirklichkeit to the synthesis. As the third Cartesian Meditation remarks during the discussion of the so-called "more pregnant concept of constitution," among the multiplicities of modes of consciousness "are included those syntheses that, with regard to their initial intention, have the typical style of verifying, and, in particular, of evidently verifying syntheses, or that of nullifying and evidently nullifying syntheses" 44 . If the objectual correlate of the former type of syntheses is the actual (wirklich) object $^{45}$, the latter corresponds to its negation, "the annulled or cancelled being," which Husserl calls Schein.

Now, if we relate such a distinction to Husserl's argument, then we can break it down as follows:

(i) Any leibliche Subjektivität entails a system of aesthetic syntheses;

(i') A conflict may arise from within my own solipsistic system of syntheses, thereby a first and "preliminary" distinction between Schein and Wirklichkeit is obtained;

(i") It might be the case that my solipsistic system of syntheses undergoes no modification, or that a modification occurs, but one that allows for no possibility of correction, thereby no distinction between Schein and Wirklichkeit is ever made. Accordingly,

(ii) The relation to a multiplicity of leibliche Subjektivitäten becomes constitutive.

(iii) If there is a multiplicity of leibliche Subjektivitäten, there is also a multiplicity of systems of aesthetic syntheses - each of them having a thing as its own "objectual" correlate and in its own mode of appearance (= i). Accordingly, only two alternatives are possible:

(iii') Either the different systems of aesthetic syntheses join together into a single system of verifying syntheses, thereby bringing about just one "actual" thing as its objectual correlate;

(iii") Or one of the systems is annulled by the other(s), and is hence unable to constitute an "actual" object as its own correlate, which turns out to be mere Schein.

44 Hua I, p. 92.

45 Hua I, p. 95. 


\section{Tertium non datur.}

As should be clear by now, the "preliminary" nature of TI.1 was due to the exclusion of the inter-subjective dimension, which Husserl holds as necessary to understand transcendental idealism.

\section{5.}

Let us try to move on to the conclusion by summing up the main outcomes of our analysis.

We have seen how the issue Husserl is dealing with when he introduces transcendental idealism is the general problem of clarifying what is "involved" in what he calls die Idee eines Existierenden überhaupt or, more specifically, in die Annahme einer existierenden Welt; it soon turns out that all the problems that fall under this general label cannot even be addressed without the assumption of a "bodily subjectivity" as an actual correlate of such a Welt, and therefore without assuming that the Dinge are Träger von Motivationen. It immediately becomes apparent what these motivations are (i.e., a "system" of kinesthetic and presenting "sensations"), and how Husserl accounts for such a "system of motivations" in terms of what he refers to as "aesthetic syntheses." If we include the de facto inter-subjective character of constitution, a new definition of "transcendental idealism" can be offered, now construed as the following thesis:

(TI.2) Die Annahme einer existierenden Welt requires (fordert) at least an animalische, or leibliche Inter-Subjektivität, i.e., a multiplicity of subjects, each endowed with a system of aesthetic syntheses. ${ }^{46}$

We have reached the end of our analysis. As announced at the outset, our major "preoccupation" was to clarify what Husserl means by "transcendental ideal-

46 We are fully aware that a full-fledged account of Husserl's "transcendental idealism," as we have tried to present it here, should also taken into consideration the so-called Willensleib (3.2), hence the notion of "spiritual motivation." Yet, if we have confined ourselves to the concept of "aesthesiological motivation" is in order to focus on the main point the present wanted to make: the importance of the Leib in general for Husserl's doctrine of "transcendental idealism" (regardless of the subjectivity being human or other). The issue of spiritual motivations would have forced us to raise the question as to the distinction between IV and V (1.2), which goes far beyond the scope of this short text: it would include, in fact, a confrontation with Husserl's early critique of "anthropologism" and the necessity of investigating the relation between the "transcendental" and the eventually "anthropological" character of the subject under scrutiny. We are very grateful to one of our anonymous reviewers for clearly pointing this out. 
ism" and the many issues and problems that potentially fall under it. Now, whether such "idealism" also represents a successful and suitable philosophical position for our troubled times, it is a question that needs to be left open. ${ }^{47}$

Daniele De Santis is assistant professor at Charles University, Prague, and his main interests include Plato, Kant, Lotze, Husserl and the phenomenological tradition, Sellars and the Pittsburgh School.

E-mail: desantis_daniele@yahoo.it

This work was supported by the European Regional Development Fund-Project "Creativity and Adaptability as Conditions of the Success of Europe in an Interrelated World" (No. CZ.02.1.01/0.0/0.0/16_019/0000734).

47 An interesting account of Husserl's "idealism," notably of the critical role it could play vis-à-vis the internalism-externalism debate, has been recently offered by Dan Zahavi in his Husserl's Legacy. Phenomenology, Metaphysics, and Transcendental Idealism, Oxford, Oxford University Press, 2017, pp. 77-136, in which, however, the constitutive role of the body, as we have been trying to discuss it in this paper, does not seem to be ever included. 